\title{
Discourse Competence in English E-Book "Contextual Teaching and Learning" for 9th Grade Students of Junior High School
}

\author{
Ulva Fatiya Rosyida ${ }^{1^{*}}$ \\ ${ }^{1}$ STAI AI Muhammad Cepu, Blora, Indonesia
}

Contact: $\quad$ Ulva Fatiya Rosyida $\otimes$ ulvablora@gmail.com

\begin{abstract}
Discourse competence is the main competence in Communicative Competence. In language teaching, the role of discourse is to achieve good communication. This study aims at describing the discourse competences in English e-book for students of Junior High School grade 9 . The data was collected by using "documentation". The spoken materials presented in section one for each unit was taken as the data. In analyzing the data, the method used here are Padan (identity) method with "referential" instrument and Agih (distributional) method. They were analyzed how the materials convey the components of discourse competence based on the model of communicative competence proposed by Celce-Murcia, et.al. From the analysis, it was found that the materials convey the components of discourse competence although there are no clear highlights showing each component.
\end{abstract}

\section{KEYWORDS:}

Discourse competence;

Spoken materials;

English e-book.

\section{Introduction}

Discourse competence is the main components in communicative competence (CC). Richard as quoted by Agustien (2008, pp. 18-21) stated that learners learn a language through using it to communicate. Discourse is language forms that are produced and interpreted as people communicate with each other ( $M$ Celce-Murcia \& Olshtain, 2000, p. 2). Therefore, discourse is the main competence in Communicative Competence.

The concept of "communicative competence" was first introduced by Dell Hymes in 1971. He argued that the concept of competence should be extended to include language use as well as sentence creation (Verhoeven, 1998, p. 390). $\mathrm{He}$ also proposed it to represent the use of language in social context or the 
observance of sociolinguistics norms of appropriacy (Savignon, 2001, p. 16). Therefore, "communicative competence" is the aspects of human competence that enables them to convey messages and to negotiate interpersonally within specific context.

Besides, Canale and Swain in 1980 defined "communicative competence" as a synthesis of knowledge of basic grammatical principles, knowledge of how language is used in social settings to perform communicative functions, and knowledge of how utterances and communicative functions can be combined according to the principles of discourse (Verhoeven, 1998, p. 390).

In Communicative Competence, Discourse Competence is as the core. Therefore, this model requires the other competences, namely Linguistic Competence, Socio-Cultural Competence, Formulaic Competence, Interactional Competence, and Strategic Competence (Marianne Celce-Murcia, 2008, pp. 45-50).

Linguistic or grammatical competence refers to sentence level, grammatical forms, and the ability to recognize the lexical, morphological, syntactic, and phonological features of a language and to make use of these features to interpret and form words and sentences. It is not demonstrated by stating a rule but by using a rule in interpretation, expression, or negotiation of meaning (Savignon, 2001, p. 16). Erica Hoff (2001, p. 260) defined linguistic competence as the ability to produce and understand well-formed, meaningful sentence. Therefore, this competence requires the competence of language structure such as phonology, morphology, and syntax.

Socio-cultural competence refers to the speakers' pragmatic knowledge (how to express messages appropriately within the overall social and cultural context of communication). Canale as quoted by Celce-Murcia (2000, p. 16) argued that this competence consists of the social and cultural knowledge required to use language appropriately with reference to formality, politeness, and other contextually defined choices. Politeness deals with perceptions, expectations, and conventional realizations of communicative strategies which 
enhance social harmony (M Celce-Murcia \& Olshtain, 2000, p. 25). We need to understand the social values of a society in order to speak politely (Holmes, 1992, p. 297). For example, a request can be made indirectly "Could you possibly pass me the salt?" or by statement "I think that is the salt beside your plate", or by adding "Please" or "If you would be so kind", etc. (Spolsky, Lee, \& Widdowson, 1998, pp. 20-21).

Strategic Competenceactivates knowledge of the other competencies and helps language users compensate for gaps or deficiencies in knowledge when they communicate (Savignon, 2001, p. 16). It involves the mastery of verbal and nonverbal strategies to compensate for breakdowns and to enhance the effectiveness of communication (Verhoeven, 1998, p. 390). For example: avoidance strategies, Time-Gaining strategiesself-monitoring, etc.

Discourse competence refers to the selection, sequencing, and arrangements of words, structures, and utterances to achieve the unified spoken message. Richard as quoted by Agustien (2008, pp. 18-21), stated that learners learn a language through using it to communicate while grammar is taught in meaningful context that focus on grammar in discourse. Discourse is language forms that are produced and interpreted as people communicate with each other (M Celce-Murcia \& Olshtain, 2000, p. 2). Regarding to the CMDT's model above, discourse competence is in the central position. They argued that discourse is the central competency. It means that it is in discourse and through discourse that the other competencies can be realized and manifested (M Celce-Murcia \& Olshtain, 2000, p. 16).

CMDT (Celce-Murcia, Dornyei, and Thurrell) argued that discourse is the central competency while the other competences can be realized ( $M$ CelceMurcia \& Olshtain, 2000, p. 16) through discourse. Two familiar concepts in discourse competence are text coherence and cohesion. Text coherence is the unity of whole sentences or utterances which produces a meaningful text, while cohesion is the structural links between elements of a text (Savignon, 2001, pp. 17-18). 
While genre refers to text types of every culture agreed by the members of speech community (Bhatia, 2004, p. 23). It has communicative purposes, generic structure, and linguistic features. The Basic English genres for $9^{\text {th }}$ grade students of Junior High School are procedure, report, and narrative. Procedure is a piece of text that gives us instructions for doing something (Anderson, 2003, p. 50). Report is a piece of text that presents information about a subject, a description and information on its parts, behaviour and qualities (Anderson, 2003 , p. 86). Narrative is a piece of text which tells a story and, in doing so, entertains or informs the reader or listener (Anderson, 2003, p. 8).

There are many studies on discourse which only analyze one part of discourse competence. For examples: "A Genre Study on the Brochure Used in Tourist Destinations, Semarang, Central Java" by Sita Nurmasitah from Semarang State University, Indonesia (2008). The result of this study described the text types used in the brochure: Description, Persuasion and Information Report. The other examples are "An Investigation into the Use of Cohesive Devices in Second Language Writings" by Mohen Ghasemi from Ferdowsi University of Mashad, Iran (2013) and "The Analysis of Cohesive Devices in Psychology Research Papers using Discourse Analysis Technique" by Aysaha Mohd Sharif, International University Malaysia (2015). Both of them analyzed the cohesive devices including the types and the problems in using them in writing.

Those studies should also analyze the other discussion on discourse to complete each other. Thus, in this research, the writer analyzes some components of discourse competence: cohesion, coherence, deixis, genre (text types), and conversation structure. They are based on the theory of Discourse Competence proposed by Celce, Murcia, Dornyei \& Thurrell (1995).

Therefore, the purpose of this research is to describe the discourse competence in English Electronic Book "Contextual Teaching and Learning" for students of Junior High School Grade 9. This book was chosen since it is one of the English e-books for students of Junior High Schools used in Indonesia. 


\section{Method}

This research belongs to qualitative research. Cohen et.al (Cohen, Manion, \& Morrison, 2007, p. 461) stated that qualitative research involves organizing and explaining the data to interpret, to describe, or to understand a theory. This research is to describe the discourse competence components of spoken materials in English e-book "Contextual Teaching and Learning" for students of Junior High School grade 9.

The population of this research is all the spoken materials presented in the book. It can be free downloaded from http:/bse.depdiknas.go.id. In analyzing the data, the writer used total sampling in which all the data were analyzed. Therefore, the population is also used as the sample. Soehartono $(2000$, p. 107) mentioned that in total sampling, the population is also used as the data sample.

In collecting the data, the writer used one instrument of data collection, namely documentation. It is conducted by classifying the written materials which are related to the problem of study (Soehartono \& Adimihardja, 2000, p. 70). The written materials in this research can also be interpreted as the spoken materials which are written down in the form of monologue, dialogue, and conversation including listening activity to be analyzed and described the components of discourse competence.

In analyzing the data, the writer used Padan (identity) method with "referential" instrument (Sudaryanto, 1993, p. 14). In this research, it is to determine, for examples: because refers to "causal conjunction", and refers to "additional conjunction", now refers to "temporal adverbs", etc. Besides, the writer used Agih (distributional) method in which the decisive factor is part of the language itself (Sudaryanto, 1993, p. 13). In this research is, for examples, to determine that reference, conjunction, substitution belong to types of "cohesive ties"; coherence can be formed by management of old and new information in a paragraph, etc. 
The analysis involves several steps. First, the data that have been collected are classified into the components of discourse competence. Next, they are presented by describing them. Finally, the writer draws some conclusions and gives suggestions for the language teachers and the next researchers who are interested in analyzing the discourse competence.

\section{Result}

The components found in the book are described below. The sample analysis of "cohesion, coherence, and deixis" is a text taken from unit 4 - Practice Activity 2.

\section{THE CHEETAH}

The cheetah is the fastest animal on land. It can run 100 kilometers an hour. It is now rare and is one of the animals which are in danger of extinction.

The cheetah has a small head and ears, and long powerful legs. It always hunts and chases its prey on open ground.

This is a different way of hunting from the other "big cats". They like to stay in and near trees to catch their prey. The cheetah is also different from other cats becauseit cannot draw in its claws.

\section{Cohesion}

Cohesion is the structural links between elements of a text (Savignon, 2001, p. 17). The analysis of cohesion consists of references, conjunctions, ellipsis, and substitutions. They are described for each part as follows.

- Reference

Pronoun: it, its, they, their. "It" and "its" refer to "the cheetah" while "they" and "their" refer to "big cats". Demonstrative: "this" in paragraph 3 refers to "the way of cheetah in hunting and chasing its prey on open ground". Temporal adverbs: "now" is found in paragraph 1 sentence 3. Other pronoun: "which" in paragraph 1 refers to "the animals"

- Conjunction

The conjunctions found in the text are "and" for addition and "because" for causal conjunction.

- Ellipsis 
The writer found only one ellipsis in the text. It is deleted clause presented in paragraph 1 line 2. The ellipsis is written bellow in the bracket.

"It is now rare and (is one of the animals which are in danger of extinction)".

The deleted clause refers to the subject "It" (the cheetah). Therefore, the sentence actually consists of two clauses: It is now rare and It is one of the animals which are in danger of extinction.

\section{Coherence}

Text coherence is the unity of whole sentences or utterances which produces a meaningful text (Savignon, 2001, p. 18). The analysis of coherence below shows the organization of old and new information. The old information is typed in bold while the new one is underlined.

The cheetah is the fastest animal on land.

It can run 100 kilometers an hour.

It is now rare and is one of the animals which are in danger of extinction.

The cheetah has a small head and ears, and long powerful legs.

It always hunts and chases its prey on open ground.

This is a different way of hunting from the other "big cats".

They like to stay in and near trees to catch their prey.

The cheetah is also different from other cats because

It cannot draw in its claws.

From the analysis, it can be seen that the old information precedes the new information. It is as the basic information which can be more added or developed. This additional information is called as "new information". This competence is important to be able to organize a text well.

\section{Deixis}

The deixis found in the text is personal, spatial, and temporal. Personal deixis applied in the text are "it, its, they, their". Spatial deixis found in the text is "this". Temporal deixis found in the text is "now". 


\section{Genre}

Genre refers to text types of every culture agreed by the members of speech community (Bhatia, 2004, p. 23). It has communicative purposes, generic structure, and linguistic features. As mentioned above that genres for students of Junior High School grade IX are Procedures, Report, and Narrative. The samples are described below.

\section{Procedures}

Based on the analysis, there is only one chapter that conveys this text presented in unit 2. In this discussion, the sample is "how to prepare baby corn soup". It is taken from listening activity (Practice - Activity 1 ).

First, boil the baby corn and let it cool

Then, grind the corn with a blender

Heat the butter

After that, put the flour into the butter after it melts

Mix the butter and flour evenly

Then, put the mix in the powdered corn with salt, pepper and milk

Finally, let it sit for five minutes in medium heat

The Social Function is to describe how to prepare baby corn soup. The Generic Structure: (1) The aim or goal; (2) The materials needed for completing the procedure; (3) Steps in the order to be done. The Linguistic Features are: Using simple present tense, imperative sentence, e.g. heat, put, etc; Using temporal conjunctions, e.g. first, then, finally, etc; using adverbs, e.g. five minutes, evenly, etc.

\section{Reports}

From the analysis, there are two units discussed "Reports" (unit 4 and unit 6). One of the samples taken from unit 4 is presented below.

\section{GORILLAS}

Gorillas are the largest of all the primates. A male gorilla can be 180 centimeters tall and can weigh 200 kilograms. Gorillas are very strong but they do not often fight. In fact they are peaceful animals. 
Gorillas live in small family groups of about 15 . In a group there is one strong, older male, some young males, and a few females with their babies. They move slowly around a large area of jungle eating leaves and bushes.

In some ways gorillas are very like humans. When they are happy, they laugh and wave their arms. When they are angry, they beat their chests. When they are sad, they cry. But they cry quietly, without any tears.

Unfortunately, people hunt and kill gorillas. They also cut down and burn their trees. There are now only about 10,000 gorillas left in the world.

The Social Function is to describe gorillas with reference to their characteristics and behaviors. The Generic Structure: (1) General classification of gorillas; (2) Description of the characteristics and habits of gorillas. The Linguistic Features: (1) Using simple present tense; 2 ) There is no temporal sequence.

\section{Narratives}

Narrative text tells a story to entertain or to amuse the reader or listener. The sample below is taken from listening activity read by the teacher. It is in Unit 8 Presentation - Activity 2.

\section{The Fox and the Crow}

Once upon a time, there lived an old lady crow that was mean and ugly. One day, Miss Crow had stolen a big piece of cheese. And then, she flew on to a branch to enjoy it.

On the other place, under the three, a sly creature, Mr. Fox, who wanted the cheese for himself, came up and spoke politely to her.

"Oh. Miss Crow, how beautiful you are! What a lovely beak, what lovely feathers you have! What pretty eyes! If only you could sing, you would be the most beautiful bird in the world!"

Very pleased to hear all of this about her, Miss Crow gave a loud croak to show that she could sing.

Of course, the moment she opened her beak, the cheese fell down, and Mr. Fox ran away with it, laughing loudly.

The Social Function of that text is to amuse or to entertain the reader or listener. The Generic Structure: (1) Orientation (This part tells the characters, the 
place, and the time. In the sample above, the characters are "The Fox" and "The Crow". The story happened in certain places near a tree, e.g. a branch of tree, under a tree. The time is not stated clearly. It just mentioned "Once upon a time"); (2) Complication (This part tells the problems that "The Crow" and "The Fox" have the same desire to get the cheese. At the beginning, "Miss Crow" got the cheese and ate them. Then, the Fox tried to praise her-if she could sing she would be the most beautiful bird in the world-so that the cheese will fall down from Crow's beak when she sing loudly); (3) Resolution (It is the last part in a narrative text which tells the audience to answer the problem. In that story, finally, when the Crow opened her beak-because of singing loudly-the cheese fell down and the Fox ran away with it); (4) Coda (It provides a moral value based on the story. From that story, the reader or listener may get a moral value, for example, not to be careless, not to be easily persuaded by others, etc).

The Linguistic Features: Using action verbs in past tense e.g. flew, ran away, etc; Using time connectives, e.g. then, Focus on specific characters "The Crow and The Fox".

\section{Conversational Structure}

In this analysis, the data sample is taken from listening activity in unit 1 Presentation - Activity 3.

Rini : Did you enjoy the picnic last week?

Tono : Yes, it was really lovely. I enjoyed seeing Borobodur. What a wonderful temple! How about you?

Rini : I did not really enjoy the picnic.

I was not so well when we arrived there.

I had to take a rest so that I missed looking around the temple.

Tono : I am sorry to hear that.

Based on the analysis, the structure includes "how to perform opening of conversation". In this data, for example, the speaker "Rini" said "Did you enjoy 
the picnic last week?" Besides, the competence involves "how to hold \& relinquish the floor (right) to talk". When Tono speaks, Rini wait until there is a sign that indicates the floor is hers and vice versa.

Furthermore, this competence contains "Adjacency pairs". They include the turns to speak and conventional signals that indicate when to take a turn and what kind of turn is expected. In this analysis, the adjacency pairs are such as question-answer and expression-response.

The sample of "question-answer" can be seen from the question asked by Rini to Tono at the beginning of conversation. So did Tono who then asked the same question to Rini. Both of them answered the questions. Meanwhile, the sample of "expression-response" occurs at the end of conversation when Rini said that she did not enjoy the picnic, Tono gave response of his concern by saying "I am sorry to hear that". Therefore, those samples can be included into "conversation structure".

However, the sample above seems to be unnatural since there is no gambit (well.., actually..., etc.) or filler (hmm.., right..., etc.) which is usually occurs in real conversation. Besides, the turn to gain the floor of conversation is quite long, such as in second turn of Tono's speaking. He speaks longer without interrupting from Rini. Meanwhile, Rini waits the signal to gain her turn to speak.

The next sample of conversation below seems to be more natural than the previous sample. It is taken from Unit 5 - Presentation - Activity 1

$\begin{array}{ll}\text { Manneke } & : \text { Hi, Jane. I've been looking for you. } \\ \text { Jane } & : \text { Hi. What's up? } \\ \text { Manneke } & : \text { I have good news for you. Your article on the tourism in Manado } \\ & \text { won the national competition. } \\ \text { Jane } & \text { : Really? It's what I want to hear. } \\ & \text { Where can I find the information about it? } \\ \text { Manneke } & : \text { I read the announcement in front of the teacher's office. }\end{array}$


Jane : : I want to see it. Thanks for the information.

Manneke : No problem. Congratulations, Jane.

Jane :Thank you.

The dialogue above seems to be more natural since it occurs in informal situation. It can be seen from Jane's first speaking Hi, What's up? In an informal situation, people respond to good news in more various ways. They usually express their amazement on the news, express great happiness, or even express that they are confused, such as Really?.. Wow.., That's great.. Wonderful.., etc.

In the dialogue, it can be found that Jane is happy with the good news. First, Jane responds her unbelievable by saying Really? Then, she responds to the good news by saying It's what I want to hear. Another "Adjancy Pair" of expression-response also occurs in that dialogue, at the end of conversation. When Manneke said Congratulations, Jane.., Jane gave response by saying Thank You..

Furthermore, the turn-taking usually occurs clearly in a telephone conversation. Below is the sample taken from Unit 7 - Presentation - Activity 2

Clerk : Front desk. May I help you?

Keiko: Yes. This is Room 2234.

May I have some extra towels please?

Clerk : Sure. I'll send some up right away.

Keiko: Oh, and could I borrow an iron?

Clerk : Certainly. I'll send one up with the towels.

Keiko: Great! Oh, I'd like a wake-up call tomorrow morning, please.

Clerk : Certainly. What time would you like us to call you?

Keiko: Umm... 7 a.m. would be fine.

Clerk : Sure.

Keiko: Thanks a lot.

Clerk :You're welcome. 
From the dialogue, there are some points dealing with turn-taking: (1) There are two speakers; Keiko and a clerk; (2) There are "adjacency pairs", such as question-answer, greeting-greeting, or expression-response; (3) The conversation occurs in telephone thus they pay more attention before taking or giving the "floor" to speak that means they have to listen carefully until they have a sign or an opportunity to take the turn; (4) Because of the third point above, it takes more time than direct conversation (face to face) and it is to avoid the overlapping in speaking.

In analyzing the conversation structure, it is actually also related to Pragmatics, for examples Cooperative Principles, Politeness, Speech Events, etc. Grice as quoted by Levinson (Levinson et al., 1983, p. 101) proposed Cooperative Principles as "make your contribution such as required at the stage at which it occurs, by the accepted purpose or direction of the talk exchange in which you are engaged". He distinguished four maxims (Palmer, 1981, p. 173): (1) Maxim of quantity (Make your contribution as informative as is required and do not make your contribution more informative than is required); (2) Maxim of Quality (Do not say what you believe to be false and do not say that for which you lack adequate evidence); (3) Maxim of Relation (Be relevant); (4) Maxim of Manner (Avoid obscurity and ambiguity, be brief and orderly).

In this case, the main purpose is for getting communication appropriately (no ambiguity, relevant, clear, informative, etc.).The samples above, mostly, show that they apply those four maxims of Cooperative Principles. In addition, some of the samples also show the use of Politeness, especially in the dialogue between a clerk and Keiko. The clerk speaks politely to Keiko as one of the customers that is being served as good as possible. The discussion also related to Speech Event which generally involves the setting (place and time), participants, the purpose, the situation (formal, informal), etc. 


\section{Discussion}

Based on the analysis, the writer found that Discourse Competence in English e-book "Contextual Teaching and Learning" for students of Junior High School grade 9 contains cohesion, coherence, deixis, genre, and conversational structure. It means that they convey the components of Discourse Competence as proposed by Celce-Murcia et.al. However, there are no clear highlights showing each component.

Cohesion, coherence, deixis, and genre are found in unit 2,4,6, and 8 . They are integrated in each of those chapters. It means, when it discuss a genre, it also includes the cohesion, coherence, and deixis since they also belong to components of a text. The English genres for 9th grade students of Junior High School are Procedure, Report, and Narrative text. Each text type has communicative purpose, the generic structure, and linguistic features.

Meanwhile, the conversational structure are found in all units (1-8), in section one. This section contains spoken materials-listening and speaking activities. The conversation structure includes:1)How to perform openings and re-openings; 2) How to hold \& relinquish the floor-the right to talk; 3) Adjacency pairs which include turns to speak and conventional signals that indicate when to take a turn and what kind of turn is expected, such as question-answer, greeting-greeting, expression-response, etc. (Widdowson, 2007, p. 36). It is also called as turn-taking (Renkema \& Schubert, 1993, p. 109).

\section{Conclusion}

Based on the analysis, it can be concluded that the materials convey the components of discourse competence. The components as proposed by CelceMurcia et.al. contain cohesion, coherence, deixis, genre, and conversation structure. However, there are no clear highlights showing each component. Basically, the analysis are related each other. For example, when analyzing a genre, it is also able to analyze the cohesion, coherence, and deixis presented in the text. 
Finally, the writer hopes that this research will be useful for language teachers in understanding each component of discourse competences along with their samples. Therefore, they can be more aware of selecting the textbooks and can develop or create the materials by themselves based on their knowledge. Meanwhile, for the next researchers who are interested in analyzing discourse competence, they may analyze the discourse competence of written materials (document research) or discourse competence in English class (action research).

\section{References}

Agustien, H. (2008). Communicative competence. Semarang.

Anderson, M. and K. A. (2003). Text types in English vol.2. Australia: Macmillan Education Australia.

Bhatia, V. K. (2004). Worlds of Written Discourse: A Genre-Based View. Retrieved from https://books.google.co.id/books?id=_A8Hf5BHO_QC

Celce-Murcia, Marianne, Z. D. and S. T. (1995). Communicative Competence: A Pedagogically Motivated Model with Content Specifications. Issues in Applied Linguistics, 6(2), 5-35.

Celce-Murcia, M, \& Olshtain, E. (2000). Discourse and Context in Language Teaching: A Guide for Language Teachers. Retrieved from https://books.google.co.id/books?id=E89KFhKefWoC

Celce-Murcia, Marianne. (2008). Rethinking the Role of Communicative Competence in Language Teaching. In Intercultural Language Use and Language Learning (pp. 41-57). https://doi.org/10.1007/978-1-4020-56390_3

Cohen, L., Manion, L., \& Morrison, K. (2007). Research Methods in Education. Retrieved from https://books.google.co.id/books?id=QUtjTJMYsFEC

Hoff, E. (2001). Language Development: Second Edition. USA: Wadsworth.

Holmes, J. (1992). An Introduction to Sociolinguistics. Retrieved from https://books.google.co.id/books?id=ouZwAAAAIAAJ

Levinson, S. C., Hattaway, M., Levinson, S. C., Anderson, S. R., Bresnan, J., Comrie, B., ... Ewen, C. J. (1983). Pragmatics. Retrieved from https://books.google.co.id/books?id=SJXr9w_IVLUC

Palmer, F. R. (1981). Semantics. Retrieved from https://books.google.co.id/books?id=UWJSaxH9GiMC

Renkema, J., \& Schubert, C. (1993). Introduction to Discourse Studies: New edition. Retrieved from https://books.google.co.id/books?id=iZx2DwAAQBAJ

Savignon, S. J. (2001). Communicative language teaching for the twenty-first century": Edited by Marianne Celce-Murcia (Marianne Celce-Murcia, ed.). USA: Heinle \& Heinle Thompson Learning. 
Soehartono, I., \& Adimihardja, K. (2000). Metode penelitian sosial: suatu teknik penelitian bidang kesejahteraan sosial dan ilmu sosial lainnya. Retrieved from https://books.google.co.id/books?id=r5JkAQAACAAJ

Spolsky, B., Lee, W. R., \& Widdowson, H. G. (1998). Sociolinguistics. Retrieved from https://books.google.co.id/books?id=diwosITLKwAC

Sudaryanto. (1993). Metode Dan Aneka Teknik Analisis Bahasa: Pengantar Penelitian Wahana Kebudayaan Secara Linguistis. Retrieved from https://books.google.co.id/books?id=uy5iAAAAMAAJ

Verhoeven, L. (1998). Sociolinguistics and Education. Edited by Florian Colbumas. The Handbook of Sociolinguistics. Oxford: Blackwell Ltd.

Widdowson, H. G. (2007). Discourse Analysis. Retrieved from https://books.google.co.id/books?id=NR4LAQAAMAAJ 